\title{
Quantification of ETS exposure in hospitality workers who have never smoked
}

\author{
Stefanie Kolb, Ulrike Brückner, Dennis Nowak, Katja Radon*
}

\begin{abstract}
Background: Environmental Tobacco Smoke (ETS) was classified as human carcinogen (K1) by the German Research Council in 1998. According to epidemiological studies, the relative risk especially for lung cancer might be twice as high in persons who have never smoked but who are in the highest exposure category, for example hospitality workers. In order to implement these results in the German regulations on occupational illnesses, a valid method is needed to retrospectively assess the cumulative ETS exposure in the hospitality environment.
\end{abstract}

Methods: A literature-based review was carried out to locate a method that can be used for the German hospitality sector. Studies assessing ETS exposure using biological markers (for example urinary cotinine, DNA adducts) or questionnaires were excluded. Biological markers are not considered relevant as they assess exposure only over the last hours, weeks or months. Self-reported exposure based on questionnaires also does not seem adequate for medico-legal purposes. Therefore, retrospective exposure assessment should be based on mathematical models to approximate past exposure.

Results: For this purpose a validated model developed by Repace and Lowrey was considered appropriate. It offers the possibility of retrospectively assessing exposure with existing parameters (such as environmental dimensions, average number of smokers, ventilation characteristics and duration of exposure). The relative risk of lung cancer can then be estimated based on the individual cumulative exposure of the worker.

Conclusion: In conclusion, having adapted it to the German hospitality sector, an existing mathematical model appears to be capable of approximating the cumulative exposure. However, the level of uncertainty of these approximations has to be taken into account, especially for diseases with a long latency period such as lung cancer.

\section{Background}

Prior to the implementation of the workplace smoking ban, Environmental Tobacco Smoke (ETS) was, except for exposure to allergens, probably the most important inhalative hazardous substance in terms of number of exposed people in many countries.

Occupational exposure to Environmental Tobacco Smoke (ETS) and subsequent health effects in workers have been frequently investigated in recent studies, especially in Europe and the USA [1-3]. In these, ETS is defined as side-stream smoke which is released by burning cigarettes. Acute symptoms like irritation of eyes and mucous membranes aside, chronic symptoms like

\footnotetext{
* Correspondence: sekretariat-radon@med.Imu.de Institute for Occupational, Social and Environmental Medicine, University Hospital of the Ludwig-Maximilians University Munich, Ziemssenstr. 1, 80336 Munich, Germany
}

(c) 2010 Kolb et al; licensee BioMed Central Ltd. This is an Open Access article distributed under the terms of the Creative Commons Attribution License (http://creativecommons.org/licenses/by/2.0), which permits unrestricted use, distribution, and reproduction in any medium, provided the original work is properly cited. exacerbation of chronic bronchial asthma, aggravation of chronic obstructive lung diseases or cardiovascular diseases [4-6] are well known effects on health. Furthermore, several international meta-analyses [7-11] indicate that ETS exposure results in significantly higher relative risks (RR) for lung carcinoma in persons who have never smoked. These studies have found that lung cancer risk is even doubled in these persons, who represent the most exposed subgroup.

Whereas for the majority of the population private ETS exposure in bars or restaurants was negligibly low, hospitality workers were submitted to unlimited exposure to ETS in Germany until 2007. Therefore, ETS exposure may be extremely high in restaurants or bars and in addition, these workplaces are the least protected by law $[12,13]$. Based upon the results of epidemiological studies, the relation between workplace exposure to ETS and the 
development of lung cancer in persons who have never smoked seems to be highly relevant in workers' compensation claims. Hence a reliable method for a valid retrospective estimation of cumulative ETS exposure is necessary.

Valid risk assessment of health effects caused by ETS is difficult due to problems with proper exposure assessment as well as it being necessary to restrict the group of exposed persons to the subgroup of those who have never smoked. So far smokers' exposure to ETS was thought to be negligibly low compared to the amount inhaled by active smoke. This opinion might change in future as a recent study from Piccardo et al. found that ETS exposure in active smokers seems be important at least in indoor environments [14]. However, at present the risk increase due to ETS in smokers and ex-smokers appears to be non-definable. Furthermore, as ETS occurs at work as well as at home or during leisure, the concentration and intensity of specific ETS indicators varies spatially and temporally. The long latency period between exposure and diseases like lung cancer, compounds the problem as epidemiological studies have to estimate exposure over a long time period.

Studies dealing with decomposition products of nicotine (like cotinine and nicotine in urine, saliva and blood) as indicators for acute ETS exposure are readily available [15-26]. Further studies investigated whether these indicators produce valid measurements of ETS exposure [20,27-46].

In contrast, valid retrospective exposure assessment of chronic ETS exposure is especially difficult as no surveillance data exists. Most existing studies used questionnaires for exposure assessment. However, these were only validated in terms of acute exposure $[47,48]$. The questionnaires mostly included items like number of smoking colleagues at work [49], duration of daily exposure and number of years at work [50].

Due to the subjectivity of this method it can not be used directly in compensation claims in Germany. Furthermore, the fact that exposure might change over years and smokers might be misclassified as non-smokers would probably complicate the acceptance of a legally defined occupational disease due to ETS exposure.

Therefore this literature-based methodological review aims for a reliable model for retrospective exposure assessment of ETS in the hospitality setting. This method should be used in the future for the determination of exposure thresholds in German workers' compensation claims.

\section{Methods}

\section{Literature-based methodological review}

A systematic literature-based methodological review was carried out using the Medline database with the following selection criteria:
Keywords:

- "tobacco smoke pollution" as a generic term for ETS (Medline Search Term-MeSH, including the terms "ETS", "second hand smoke" and "passive smoking")

- "restaurant" as generic term for hospitality setting (including the terms "disco", "bar", "tavern" and "pub")

- "occupational exposure" or "risk assessment" for exposure and risk assessment

The keywords were combined in the following way:

((“Tobacco Smoke Pollution”[Mesh] AND (((("Restaurants" [Mesh]) OR "Risk assessment" [Mesh]) OR "occupational exposure" [Mesh]))).

Using the function "limits", further selection criteria were chosen:

- Publication language: German and English

- Time period: 1990 to June 2007

- This time period was selected due to the fact that before 1990 most studies focused on ETS exposure at home.

This method generated 575 publications. First the abstracts of all 575 publications were screened; 94 abstracts indicated that they addressed the above mentioned aims of this review and were included in the further analysis. The remaining 481 publications were excluded from further analysis mostly because they contained the following:

- health effects of active and passive smoking in children, adolescents and adults in general

- health effects of maternal smoking and the embryonic development of their children

- methods, results, advantages and disadvantages of non-smoking programmes as well as attitudes of hospitality workers and guests towards these programmes.

- possible influences of the tobacco industry on medical research

- development of new methods for quantification of acute and subacute ETS exposure like DNAadducts.

The remaining 94 articles were reviewed in full. Since all publications using a mathematical model for retrospective exposure assessment were based on a model developed in the 1980s, a further 15 publications were included [20,51-64] despite their earlier date of publication. Further publications were found in the bibliographies of the selected papers $(n=24)$. 
87 publications of these 133 publications were excluded for the following reasons:

- Exposure- and risk assessment did not deal specifically with the hospitality setting $(\mathrm{N}=33)$

- Comments and critical evaluation of existing publications and methods $(\mathrm{N}=13)$; these were implemented in the discussion only

- Outcomes which are not relevant for the present question (e.g. acute symptoms of ETS exposure) $(\mathrm{N}=8)$ - Discussion of different methods of measurements regarding estimation of acute ETS exposure $(\mathrm{N}=21)$ - Publications dealing with advantages and disadvantages of different methods of measurements of acute ETS exposure $(n=12)$.

The remaining 46 publications were divided into the three categories mentioned (Table 1).

The following information was extracted from each study if available:

- number and type of participants

- origin of study

- workplace (hospitality setting, others)

- investigated diseases

- air measurements: results for nicotine

- relative or absolute risk for the development of lung cancer due to ETS.

Only few authors restricted their analysis to persons who have never smoked, whereas the definition of those varied from the consumption of 0 and 100 cigarettes $[65,66]$ up to 400 cigarettes $[67,68]$ over a lifetime. All other studies used non-smokers or merged never- and ex-smokers into non-smokers. This classification is based on the hypothesis that the risk for lung cancer due to ETS exposure is no longer increased significantly after a lag period of 15 years [50].

\section{Results}

Models for calculation of indoor ETS exposure Calculation of "cigarette equivalents"

Puntoni et al. [69] developed a mathematical model for the calculation of lung cancer risk at low cigarette consumption ( $<5$ cigarettes/day). By extrapolating data of nine cohort studies, the authors showed that there is a linear correlation between ETS exposure and lung cancer, even at low-dose low-level exposure. Based on these models Puntoni et al. calculated "cigarette equivalents" for ETS, converting ETS exposure to a corresponding number of actively smoked cigarettes. The cotinine plasma concentration of passive smokers was defined as $0.6-1.0 \%$ of the cotinine plasma concentration of active smokers [64]. The daily mean consumption of 20 cigarettes of active smokers would therefore be equivalent to $0.12-0.20$ cigarettes/day of ETS for a passive smoker.

\section{Models for retrospective exposure assessment}

Mathematical models for retrospective exposure assessment are predominantly based on a model by Repace and Lowrey [58-61,70]. This model was developed for assessing the risk of lung cancer caused by ETS and thoroughly validated [71,72].

Estimate of nicotine exposure in the workplace Repace and Lowrey assumed that ETS exposure is proportional to the smoker density $\left(D_{R}\right)$ and the inversely proportional to the air exchange rate $\left(\Phi_{\mathrm{v}}\right)$ measured as air changes per hour $[58,59]$. The smoker density is hereby based on the mean number of smokers in a room in relation to the room's volume and the mean number of cigarettes smoked per hour and per smoker. Repace and Lowrey used data from epidemiological studies in the USA, giving a smoking prevalence of $25 \%$ and the average number of smoked cigarettes of $2 / \mathrm{h}$ [72].

For example, a restaurant with an area of $100 \mathrm{~m}^{2}, 70$ available seats and a ceiling height of $4 \mathrm{~m}$ results in a room volume of $400 \mathrm{~m}^{3}$. With a smoker prevalence of $25 \%$ active smokers, the smoke density is as follows (Equation 1):

$$
\text { Smoke density } D_{R}=70 \times 0.25 / 400=4.5 \text { smoker } / 100 \mathrm{~m}^{3}
$$

Nicotine concentration in indoor air was, although not representing a carcinogen, used as an indicator for ETS exposure [60] as it correlates with ETS exposure. However, the model was validated using other ETS indicators as well. Nicotine concentration $\left(\mu \mathrm{g} / \mathrm{m}^{3}\right)$ at the workplace was calculated as a function of smoke density $D_{R}$

Table 1 Classification of the selected publications

\begin{tabular}{l}
$\begin{array}{l}\text { Category } \\
\text { [References] }\end{array}$ \\
$\begin{array}{l}\text { Number of publications } \\
\text { development of these models }\end{array}$ \\
\begin{tabular}{l} 
2. Publications dealing with acute exposure assessment especially in the hospitality industry \\
\hline 3. Retrospective exposure and risk assessment of diseases associated with ETS exposure in workers of the \\
hospitality industry
\end{tabular} \\
\hline
\end{tabular}


$\left(\right.$ smoker $/ 100 \mathrm{~m}^{3}$ ) and air exchange rate $\Phi_{\mathrm{v}}$ (air-changes/ hour) (Equation 2).

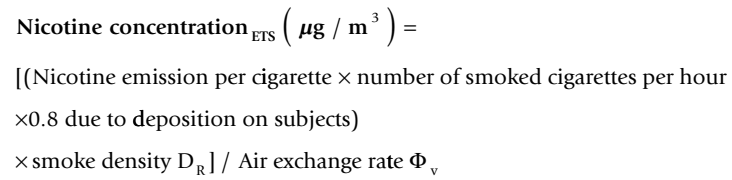

Mean nicotine emission is $1400 \mu \mathrm{g}$ nicotine/cigarette based on laboratory measurements.

The air exchange rate is based on the number of persons per room multiplied by the statutory ventilation rate (for a US restaurant 10l/second/person). This product is divided by the room volume in $\mathrm{m}^{3}$. In the example stated above this would result in 6.25 air exchanges/ hour (Equation 3).

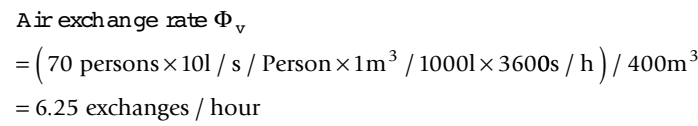

Using equation 2 this example leads to

$$
\begin{aligned}
& \text { Nicotine } \operatorname{ETS}\left(\mu \mathrm{g} / \mathrm{m}^{3}\right) \\
& =[(1400 \mu \mathrm{g} \times 2 \times 0.8) \times 4.5 \text { smokers }] / 100 \mathrm{~m}^{3} / 6.25 / \mathrm{h}=15.7 \mu \mathrm{g} / \mathrm{m}^{3} .
\end{aligned}
$$

The results of this formula were validated with measurements and showed good agreement $[58,60]$. To retrospectively calculate the exposure of an individual using these equations, certain parameters like company data (ventilation, number of guests), data from epidemiological studies (smoking prevalence in the population) and laboratory data (mean nicotine emission of a cigarette) are required (Table 2).

Further exposure models Klepeis [73] investigated if indirect methods could lead to a valid estimation of ETS exposure in everyday life. Furthermore, Klepeis and colleagues [74,75] developed models regarding the dissemination of smoking sources. Based on these results, ETS produced by one cigarette will disperse within 12 to 80 minutes throughout an entire room. Similarly time exposure models were developed by Ott et al. [76] and in general these models for retrospective exposure assessment based on the physical law of conversation of mass were very similar. They were validated in experimental tests and epidemiological studies. An overview of the different models and their derivation is given by Ott [77].

Estimate of lung cancer risk Repace and Lowrey also used their exposure model for the calculation of lung cancer risk caused by ETS exposure $[2,59,70,71]$. According to the publications of Doll and Peto [53], Puntoni [69] and other authors [51,52] they assumed a linear dose-response relationship. The baseline risk for lung cancer in non-ETS exposed persons who have never smoked was derived from epidemiological studies $[56,57,70,72]$. Based on these results Repace and Lowrey calculated the additional lung cancer risk at the workplace [72] and applied it to the hospitality setting [71]. Basic lung cancer risk in the USA was given as 7 cases/ 1000 persons amongst non-smoking unexposed women [71,78].

For risk calculation of occupationally exposed workers, duration of employment and daily working hours were taken into account. Repace and Lowrey assumed 40 years of employment with 260 working days per year and 6.7 working hours per day. Respiratory minute volume was defined as $1 \mathrm{~m}^{3} / \mathrm{h}$ for physically easy work. According to the above calculations, this results in one additional death from lung cancer per $7.5 \mu \mathrm{g} / \mathrm{m}^{3}$ of nicotine in the air in 1000 employees [71,72] (Table 3).

However, it should be borne in mind that the epidemiological data for calculating the additional deaths is based on data from the USA. For a reliable calculation in other countries, equivalent epidemiological data should be used.

\section{Acute ETS exposure in the hospitality environment}

As stated above, acutely measured nicotine concentration is, especially after implementation of the smoking ban, not suitable for estimating chronic ETS exposure. However, these studies are used to illustrate the typical exposure level [79-98] (additional file 1). As expected

Table 2 Required parameters for Repace and Lowrey's model regarding retrospective exposure assessment of air nicotine concentration

\begin{tabular}{ll}
\hline Parameter (Unit) & Data source \\
\hline Room volume $\mathrm{V}$ (in $\mathrm{m}^{3}$ ) & Fixed size for each hospitality environment \\
\hline Number of guests/seats (in persons) & Mandatory legal standards define the maximum occupancy \\
\hline Ventilation rate (in I/s pro Person) & In Germany: E DIN EN 15251/ASR (defined standard) for uninhabited buildings \\
\hline $\begin{array}{l}\text { Nicotine emission per cigarette (in mg nicotine per } \\
\text { cigarette) }\end{array}$ & $\begin{array}{l}\text { Means could be derived from measurements and studies of the accordant time } \\
\text { period }\end{array}$ \\
\hline Loss by nicotine deposit on surfaces (in percent) & Known physical parameter (80\%) [58] \\
\hline Number of smoked cigarettes per smoker (in/h) & Epidemiological data for observed time period \\
\hline Smoker prevalence (in \%) & Epidemiological data for observed time period \\
\hline
\end{tabular}


Table 3 Calculation of additional deaths given an occupational exposure to ETS of 40 years based on the model by Repace und Lowrey in comparison to the baseline risk [71].

\begin{tabular}{llrr}
\hline Country & Place of ETS exposure & Estimated nicotine exposure $\left(\boldsymbol{\mu g} / \mathbf{m}^{\mathbf{3}}\right)$ & Number of lung cancer deaths per $\mathbf{1 0 0 0}$ persons \\
\hline USA & No exposure & 0 & 7 \\
& Only domestic exposure & 4.3 & 10 \\
& Office & 11.2 & $11.5^{*}(8.5) \#$ \\
& Restaurant & 15.7 & $12.0^{*}(9.0) \#$ \\
& Smoker club & 20.3 & $12.7^{*}(9.7) \#$ \\
\end{tabular}

Data for USA. (* Occupational and domestic exposure, \# only occupational exposure)

the results of these studies vary largely, most likely due to different exposure situations in the individual countries. Bohannon and colleagues [82] showed that mean nicotine air concentration in six different countries could vary up to a factor of 10 . In Germany, Bolte et al. found nicotine concentrations ranging from 71 to 450 $\mu \mathrm{g} / \mathrm{m}^{3}$ in discos [83]. After inputting this data into Repace and Lowrey's model, a lifetime risk of developing lung cancer of 16.5 to 67.0 per 1000 persons due to occupational ETS exposure is calculated. The large variation of these results outlines the importance of a valid retrospective exposure assessment.

Risk assessment of diseases associated with ETS exposure in workers of the hospitality industry

In total, four studies regarding retrospective exposure and assessing the risk of workers in the hospitality industry were found. Hedley et al. [99], Mulcahy and Repace [100] as well as Siegel and Skeer [13] used the above mentioned model of Repace and colleagues [2,59,72] for studies in Hong Kong [99], Ireland [100] and the USA [13]. The Jamrozik's approach [101] was different, estimating risks attributable to ETS in the hospitality industry in Great Britain.

\section{Hospitality workers in Hong Kong}

Hedley et al. [99] used Repace and Lowrey's model $[58,59,72]$ for calculating the additional risk of developing lung cancer and heart disease caused by ETS exposure at the workplace. Urinary cotinine concentrations were converted to ETS exposure as mentioned in Repace and Lowrey's model. According to their model $[2,61]$, lung cancer and heart disease mortality for nonsmoking hospitality workers in Hong Kong increased by 30 cases per 1000 workers due to ETS exposure over 40 years. The authors stated a ratio of 10:1 (cardiac events to lung cancer) resulting in 3 additional deaths per 1000 workers due to lung cancer.

\section{Hospitality workers in bars in Ireland}

Mulcahy and Repace estimated mean saliva cotinine concentrations of $7.4 \mathrm{ng} / \mathrm{ml}$ based on air carbon monoxide measurements in 14 Irish bars [100]. Using Repace and Lowrey's approach [2], they calculated an additional lung cancer mortality of 18 per 1,000 for the 28,000 fulltime working bar staff in Ireland given 40 years of working time.

This study was published only in the form of congress proceedings and only a few details were given with regard to the approach used. Therefore, results have to be interpreted carefully.

\section{Hospitality workers in the USA}

Siegel and Skeer estimated the number of additional lung cancer cases in the hospitality industry in the USA [13]. They included current literature regarding nicotine exposure measurements in bars, billiard and bowling centres, bingo halls and restaurants in the USA (Table 4). Based upon the nicotine concentrations, the number of the additional lung cancer cases was calculated using Repace and Lowrey's model $[2,59,72]$. This resulted in an additional 1.0 to 4.1 lung cancer deaths per 1000 workers over a 40 year working period. As expected, mortality was associated with higher exposure concentrations (weighted mean nicotine concentration $31.1 \mu \mathrm{g} / \mathrm{m}^{3}$ ) and longer working shifts (40 hours/week) in bar staff.

\section{Hospitality worker in Great Britain}

Jamrozik [101] used a different approach for estimating the attributable risk of dying from lung cancer, coronary artery disease and stroke in the hospitality industry in UK Based on a study from New Zealand [102], he estimated a mean relative risk of 1.24 for lung cancer caused by ETS exposure at home. A study from Great Britain [21] projected an increase in exposure by 3.04 times in non-smoking hospitality workers in comparison to people only exposed at home, resulting in a relative risk of 1.73 for lung cancer, 1.61 for coronary heart disease and 2.37 for strokes amongst workers in the hospitality industry. Based on this data, the author estimated that 54 annual deaths were caused by ETS in the UK hospitality sector, 15 of which from lung cancer.

\section{Discussion}

The aim of this publication was to review the existing literature on ETS in order to determine a reliable model for retrospective exposure assessment of ETS in the hospitality industry. 
Table 4 Additional deaths for occupational and private ETS exposure over $\mathbf{4 0}$ years based on the formula by Repace and Lowrey as well as epidemiological studies [71]

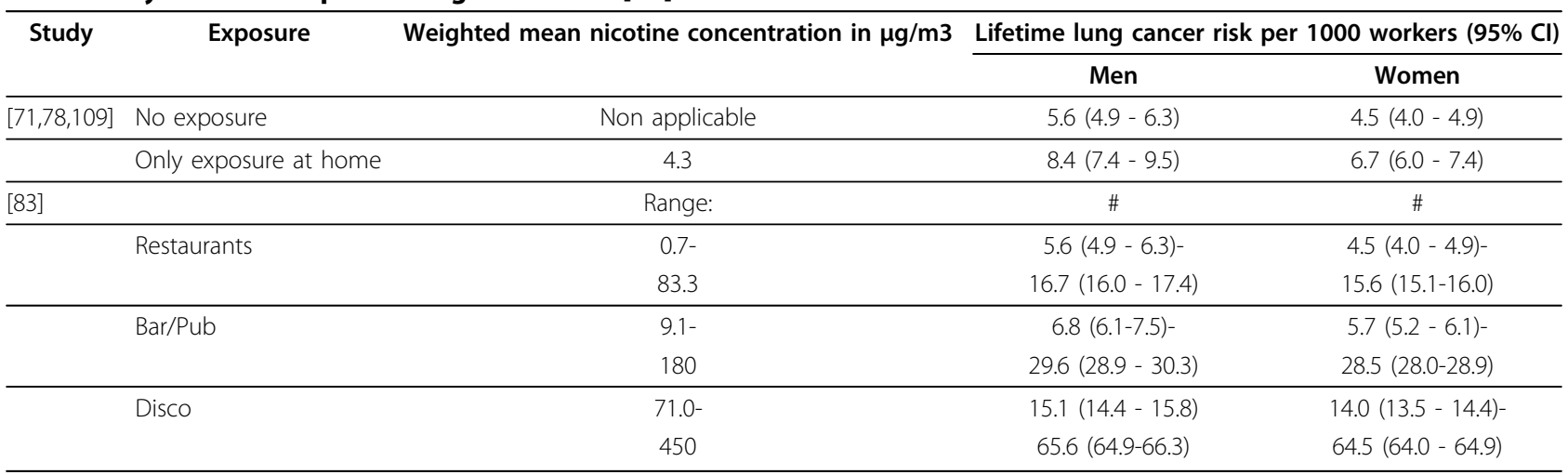

\# Exposure only at workplace

Neither questionnaires nor markers of acute exposure could be used in this context due to potential lack of validity of self-reported exposure [103].

The review indicated that a model by Repace and Lowrey which had already been developed in the 1980s might best serve this purpose $[2,13,58,61,70-72,99,100]$. By applying different parameters (room volume, ventilation and mean number of smoked cigarettes per hour), ETS exposure in the hospitality industry can be estimated. Using this model, the additional risk for lung cancer due to ETS exposure at work can be calculated taking the exposure duration into account.

\section{Methods}

The choice of keywords in this literature review was based on the given problem. By using a combination of several MeSH-terms, it was ensured that the search results were as complete as possible. The study population was not restricted to hospitality workers as exposure assessment models from other sectors might have been used [13,71,99-101]. Due to the fact that before 1990 ETS exposure was mostly investigated at home, publications prior to this date were initially excluded. However, it was noticed that the available studies dealing with ETS exposure in the hospitality industry referred to a model which was already developed in the 1980s. Hence an additional 15 publications which had been shown to be relevant to the topic were included [20,51-64].

\section{Results}

\section{Cigarette equivalents}

Puntoni et al. [69] developed a model for calculating lung cancer risk due to ETS exposure at low cigarette consumption levels ( $<5$ cigarettes/day). Several studies showed that a linear correlation to estimate the doseresponse relationship between ETS and lung cancer is applicable [51-53,69]. The linear correlation was questioned in some publications [104,105]. However, it must be considered that financial support from the tobacco industry could have influenced the objectivity of this author [106].

\section{Further models for retrospective assessment of ETS} exposure

All further models for retrospective assessment of ETS exposure at work and in the environment were based on the model published by Repace and Lowrey. Other models, which assumed life-long smoking habits $[76,77]$ found results consistent with Repace and Lowrey, who had used epidemiological data regarding the retrospective assessment of smoking habits in the hospitality industry. Several epidemiological studies and Monte Carlo simulations validated this model [2]. However, it has to be taken into account that nearly every non-smoker is exposed to ETS in daily life. Due to the fact that the average occupational exposure is much higher in the hospitality industry than at home, the additional risk seems to be clearly definable. Nevertheless, it has to be taken into account that mathematical models are only approximations of real exposure, especially if the latency period between exposure and disease is long.

\section{Conversion of exposure amount in additional lung cancer} risk due to ETS exposure in the hospitality industry

Repace and Lowrey [2,59,72] defined a lifelong working time of 40 years as the basis for calculating the additional lung cancer risk due to ETS exposure at work. Mulcahy and Repace [100] reported that only $45 \%$ of bar workers are employed in this sector for more than 10 years, whereas in other areas, such as discos, the working time could even be shorter. This has to be taken into account when calculating the additional number of lung cancer deaths. In contrast to the individual number of working years, assessment of the individual mean weekly working time could be difficult due to the high frequency of part time jobs in the hospitality industry. 
This literature-based methodological review shows that in general the model of Repace and Lowrey is suitable for retrospective exposure assessment of ETS exposure in the hospitality setting $[13,71,100,107]$. The resulting exposure calculated using this model reflects the real exposure validly, as demonstrated in a metaanalysis by Stayner et al [10]:

Using Repace and Lowrey, an additional lung cancer death per $7.5 \mu \mathrm{g} / \mathrm{m}^{3}$ nicotine at the workplace arises given employment duration of 40 years in the USA. Using Repace and Lowrey's formula, the predicted nicotine exposure at an office workplace is $11.2 \mu \mathrm{g} / \mathrm{m}^{3}$. This leads to 8.5 lung cancer deaths per 1000 workers without private exposure in comparison to $7 / 1000$ for workers without occupational and private exposure and an RR of: $R R=8.5 / 7=1.21$.

In comparison with the total RR (relative risk) of 1.24 (95\% CI 1.18-1.29) for occupationally exposed people reported by Stayner et al. [10], the calculation by Repace and Lowrey lies within the $95 \%$ confidence interval of the results by Stayner et al.

However, type of occupation is important. For the most highly exposed people a RR of 2.01 (95\% CI 1.332.60) was shown in this meta-analysis. Using data from a review by Siegel [96] with nicotine concentrations ranging from 7.4 to $65.5 \mu \mathrm{g} / \mathrm{m}^{3}$ in bars, a relative risk of 1.14 to 2.25 can be calculated. These results would suggest that Repace and Lowrey's calculation may even underestimate the real relative risk.

However, the transfer of these methods from a population to individuals is difficult [108]. One of the major problems is the small number of non-smokers with lung cancer [109]. This results in studies based on small samples and thus large confidence intervals. Furthermore, the wide spread of measurements demonstrates the differences in the extent of workplace exposure and emphasizes the importance of individual exposure assessments.

\section{Assessment of acute ETS exposure by air nicotine concentration in the hospitality industry}

The validity of Repace and Lowrey's model was illustrated in a summary of studies using air nicotine concentrations as a leading parameter for ETS exposure in the hospitality industry. However, other markers like total dust exposure or cotinine concentration in body fluids led to similar results $[2,71]$. The appropriate correlation of atmospheric and biological markers in studies of ETS exposure has been discussed in detail by Repace et al. [110].

A study by Bolte et al. [83] showed that prior to the implementation of the smoking ban the mean nicotine air concentration in restaurants, cafes, pubs and bars in Germany was comparable to other European studies $[83,86,94,95,97]$. In contrast, the nicotine air concentrations in discos and nightclubs were higher in Germany than in other European studies $[83,86,94,95,97]$.

Hence exposure differences in different countries as well as in different hospitality environments have to be taken into account. Based on the nicotine concentrations detected in the hospitality industry in Germany before the smoking ban [83], the lung cancer risk of a non-smoking restaurant worker after 40 working years could be greater by a factor of 3 . This factor could increase to 5.8 in bar workers and to 13.0 in disco employees, who represent the most highly exposed group (Table 4). Even though the underlying base risk was obtained from the USA, these numbers indicate the legal relevance of this problem.

This data is concordant with the relative risks reported in epidemiological studies (see above).

\section{Retrospective exposure assessment and calculation of lung} cancer risk for hospitality workers

The results presented here are based on lung cancer as an outcome, because for common diseases such as cardiac events the additional risk due to ETS cannot be clearly defined for workers' claims compensation in Germany.

Overall, the studies show a clear additional risk of lung cancer mortality in hospitality workers. Estimates based on Repace and Lowrey's model resulted in an additional risk for lung cancer mortality of 1 per 1000 workers in bowling alleys in the USA and 18 per 1000 workers in bars in Ireland. Here it has to be taken into account that different respiratory minute volumes were used. Hedley et al. used a respiratory minute volume of $1 \mathrm{~m}^{3} / \mathrm{h}$ in line with light physical work [99]. In the hospitality industry moderately heavy physical work can be assumed. Thereby the publication underestimates the real risk at 3 per 1000 workers.

The considerably higher risk shown in the publication of Mulcahy and Repace is due to the underlying higher exposure amount. Unfortunately, further details were not mentioned in this paper [100].

Jamrozik [101] calculated a relative risk of 1.73 for lung cancer due to ETS of workers in pubs, night clubs and bars. However, neither the derivation of the relative risk nor the confidence intervals were explained in detail.

\section{Conclusion}

Prior to the introduction of a partial or full smoking ban in many countries, ETS exposure was a cause of health risks in hospitality workers who never smoked. Based on the available data, employees working in bars, pubs, discos and night clubs in particular are exposed to high levels of ETS. 
The main problem in calculating the risk of lung cancer due to ETS exposure results from the long latency period between exposure and disease. Retrospective exposure assessment for workers' compensation claims can be based on mathematical models where direct exposure measurement is not feasible.

Repace and Lowrey's model uses retrospectively determined parameters like room volume, number of seats, ventilation rate as well as nicotine concentration per cigarette to calculate nicotine concentration as leading parameter for ETS exposure. Data regarding smoker prevalence and number of smoked cigarettes per smoker and hour can be obtained from epidemiological studies. If the working time is known, the additional lung cancer risk for exposed workers can be calculated and compared with epidemiological data of basic lung cancer risk of non-smokers.

\section{Additional material}

Additional file 1: International studies for assessing acute air nicotine exposure in the hospitality setting: The provided table shows international studies dealing with the assessment of acute air nicotine exposure in the hospitality setting. As expected the results of these studies vary largely, most likely due to different exposure situations in the individual countries.

\section{Abbreviations}

DNA: Desoxyribonucleic Acid; ETS: Environmental Tobacco Smoke; MeSH: Medline Search Term; RR: Relative Risk; USA: United States of America; UK: United Kingdom

\section{Acknowledgements}

The project has been funded by grants from the German Statutory Accidents Insurance. We would like to thank Kurt Straif (International Agency for Research on Cancer, Lyon) and Thomas Brüning (Research Institute of Occupational Medicine German Social Accident Insurance) as well as Betty Bisdorff (Institute for Occupational, Social and Environmental Medicine) for their support.

\section{Authors' contributions}

DN and KR conceived the study and helped to draft the manuscript. SK and UB organised the literature-based methodological review. SK drafted the manuscript. All authors read and approved the final manuscript.

\section{Competing interests}

The authors declare that they have no competing interests.

Received: 27 January 2010 Accepted: 12 August 2010 Published: 12 August 2010

\section{References}

1. Hammond SK: Exposure of U.S. workers to environmental tobacco smoke. Environ Health Perspect 1999, 107(Suppl 2):329-340.

2. Repace JL, Jinot J, Bayard S, Emmons K, Hammond SK: Air nicotine and saliva cotinine as indicators of workplace passive smoking exposure and risk. Risk Anal 1998, 18:71-83.

3. Riboli E, Preston-Martin S, Saracci R, Haley NJ, Trichopoulos D, Becher H, Burch JD, Fontham ET, Gao YT, Jindal SK, et al: Exposure of nonsmoking women to environmental tobacco smoke: a 10-country collaborative study. Cancer Causes Control 1990, 1:243-252.
4. Proposed Identification of Environmental Tobacco Smoke as a Toxic Air Contaminant. California Environmental Protection Agency 2005.

5. He J, Vupputuri S, Allen K, Prerost MR, Hughes J, Whelton PK: Passive smoking and the risk of coronary heart disease-a meta-analysis of epidemiologic studies. N Engl J Med 1999, 340:920-926.

6. He Y, Lam TH, Jiang B, Wang J, Sai X, Fan L, Li X, Qin Y, Hu FB: Passive smoking and risk of peripheral arterial disease and ischemic stroke in Chinese women who never smoked. Circulation 2008, 118:1535-1540.

7. Boffetta P: Involuntary smoking and lung cancer. Scand J Work Environ Health 2002, 28(Suppl 2):30-40.

8. Brown KG: Lung cancer and environmental tobacco smoke: occupational risk to nonsmokers. Environ Health Perspect 1999, 107(Suppl 6):885-890.

9. Lubin $\mathrm{JH}$ : Estimating lung cancer risk with exposure to environmental tobacco smoke. Environ Health Perspect 1999, 107(Suppl 6):879-883.

10. Stayner L, Bena J, Sasco AJ, Smith R, Steenland K, Kreuzer M, Straif K: Lung cancer risk and workplace exposure to environmental tobacco smoke. Am J Public Health 2007, 97:545-551.

11. Taylor R, Cumming R, Woodward A, Black M: Passive smoking and lung cancer: a cumulative meta-analysis. Aust N Z J Public Health 2001, 25:203-211.

12. Siegel M, Barbeau EM, Osinubi OY: The impact of tobacco use and secondhand smoke on hospitality workers. Clin Occup Environ Med 2006 5:31-42.

13. Siegel $M$, Skeer M: Exposure to secondhand smoke and excess lung cancer mortality risk among workers in the "5 B's": bars, bowling alleys, billiard halls, betting establishments, and bingo parlours. Tob Control 2003, 12:333-338.

14. Piccardo MT, Stella A, Valerio F: Is the smokers exposure to environmental tobacco smoke negligible? Environ Health 9:5.

15. Indoor air quality in hospitality venues before and after implementation of a clean indoor air law-Western New York, 2003. MMWR Morb Mortal Wkly Rep 2004, 53:1038-1041.

16. Bates MN, Fawcett J, Dickson S, Berezowski R, Garrett N: Exposure of hospitality workers to environmental tobacco smoke. Tob Control 2002, 11:125-129.

17. Dimich-Ward $H$, Gee $H$, Brauer $M$, Leung $V$ : Analysis of nicotine and cotinine in the hair of hospitality workers exposed to environmental tobacco smoke. J Occup Environ Med 1997, 39:946-948.

18. Edwards R, Hasselholdt CP, Hargreaves K, Probert C, Holford R, Hart J, Van Tongeren $\mathrm{M}$, Watson AF: Levels of second hand smoke in pubs and bars by deprivation and food-serving status: a cross-sectional study from North West England. BMC Public Health 2006, 6:42.

19. Fowles J, Christophersen A, Fernando D, Lea R, Woodward A, Dickson S, Hosking M, Berezowski R: Secondhand tobacco smoke exposure in New Zealand bars: results prior to implementation of the bar smoking ban. $N$ Z Med J 2006, 119:U1931.

20. Husgafvel-Pursiainen $K$, Sorsa $M$, Engstrom $K$, Einisto $P$ : Passive smoking at work: biochemical and biological measures of exposure to environmental tobacco smoke. Int Arch Occup Environ Health 1987 59:337-345.

21. Jarvis MJ, Foulds J, Feyerabend C: Exposure to passive smoking among bar staff. Br J Addict 1992, 87:111-113.

22. Lambert WE, Samet JM, Spengler JD: Environmental tobacco smoke concentrations in no-smoking and smoking sections of restaurants. Am J Public Health 1993, 83:1339-1341.

23. Laranjeira R, Pillon S, Dunn J: Environmental tobacco smoke exposure among non-smoking waiters: measurement of expired carbon monoxide levels. Sao Paulo Med J 2000, 118:89-92.

24. McGhee SM, Hedley AJ, Ho LM: Passive smoking and its impact on employers and employees in Hong Kong. Occup Environ Med 2002, 59:842-846.

25. McNabola A, Broderick B, Johnston P, Gill L: Effects of the smoking ban on benzene and 1,3-butadiene levels in pubs in Dublin. J Environ Sci Health A Tox Hazard Subst Environ Eng 2006, 41:799-810.

26. Vardavas $\mathrm{Cl}$, Kondilis B, Travers MJ, Petsetaki E, Tountas Y, Kafatos AG: Environmental tobacco smoke in hospitality venues in Greece. BMC Public Health 2007, 7:302.

27. Al-Delaimy WK: Hair as a biomarker for exposure to tobacco smoke. Tob Control 2002, 11:176-182 
28. Al-Delaimy WK, Crane J, Woodward A: Is the hair nicotine level a more accurate biomarker of environmental tobacco smoke exposure than urine cotinine? J Epidemiol Community Health 2002, 56:66-71.

29. Benowitz NL: Biomarkers of environmental tobacco smoke exposure. Environ Health Perspect 1999, 107(Suppl 2):349-355.

30. Collier AC, Pritsos CA: Environmental tobacco smoke in the workplace: markers of exposure, polymorphic enzymes and implications for disease state. Chem Biol Interact 2003, 146:211-224.

31. Cope G, Nayyar P, Wilkinson L, Holder R: Simple colorimetric test to quantify exposure to environmental tobacco smoke: occupational health study. Ann Clin Biochem 2000, 37(Pt 6):795-796.

32. Daisey JM: Tracers for assessing exposure to environmental tobacco smoke: what are they tracing? Environ Health Perspect 1999, 107(Suppl 2):319-327.

33. Delfino RJ, Ernst P, Jaakkola MS, Solomon S, Becklake MR: Questionnaire assessments of recent exposure to environmental tobacco smoke in relation to salivary cotinine. Eur Respir J 1993, 6:1104-1108.

34. Gourgoulianis Kl, Gogou E, Hamos V, Molyvdas PA: Indoor maternal smoking doubles adolescents' exhaled carbon monoxide. Acta Paediatr 2002, 91:712-713.

35. Hatsukami DK, Benowitz NL, Rennard SI, Oncken C, Hecht SS: Biomarkers to assess the utility of potential reduced exposure tobacco products. Nicotine Tob Res 2006, 8:169-191.

36. Husgafvel-Pursiainen K: Biomarkers in the assessment of exposure and the biological effects of environmental tobacco smoke. Scand J Work Environ Health 2002, 28(Suppl 2):21-29.

37. Iwase A, Aiba M, Kira S: Respiratory nicotine absorption in non-smoking females during passive smoking. Int Arch Occup Environ Health 1991, 63:139-143.

38. Jaakkola MS, Jaakkola JJ: Assessment of exposure to environmental tobacco smoke. Eur Respir J 1997, 10:2384-2397.

39. LaKind JS, Ginevan ME, Naiman DQ, James AC, Jenkins RA, Dourson ML, Felter SP, Graves CG, Tardiff RG: Distribution of exposure concentrations and doses for constituents of environmental tobacco smoke. Risk Anal 1999, 19:375-390.

40. Lando HA, McGovern PG, Kelder SH, Jeffery RW, Forster JL: Use of carbon monoxide breath validation in assessing exposure to cigarette smoke in a worksite population. Health Psychol 1991, 10:296-301.

41. Morabia A, Bernstein MS, Curtin F, Berode M: Validation of self-reported smoking status by simultaneous measurement of carbon monoxide and salivary thiocyanate. Prev Med 2001, 32:82-88.

42. Pendergrass SM, Krake AM, Jaycox LB: Development of a versatile method for the detection of nicotine in air. Aihaj 2000, 61:469-472.

43. Scherer $G$, Richter E: Biomonitoring exposure to environmental tobacco smoke (ETS): a critical reappraisal. Hum Exp Toxicol 1997, 16:449-459.

44. Weaver VM, Buckley TJ, Groopman JD: Approaches to environmental exposure assessment in children. Environ Health Perspect 1998, 106(Suppl 3):827-832.

45. Willemsen MC, Brug J, Uges DR, Vos de Wael ML: Validity and reliability of self-reported exposure to environmental tobacco smoke in work offices. J Occup Environ Med 1997, 39:1111-1114.

46. Woodward A, al-Delaimy W: Measures of exposure to environmental tobacco smoke. Validity, precision, and relevance. Ann N Y Acad Sci 1999, 895:156-172.

47. Jarvis MJ, Goddard E, Higgins V, Feyerabend C, Bryant A, Cook DG: Children's exposure to passive smoking in England since the 1980s: cotinine evidence from population surveys. Bmj 2000, 321:343-345.

48. Vineis P, Airoldi L, Veglia F, Olgiati L, Pastorelli R, Autrup H, Dunning A, Garte S, Gormally E, Hainaut P, Malaveille C, Matullo G, Peluso M, Overvad K Tjonneland A, Clavel-Chapelon F, Boeing H, Krogh V, Palli D, Panico S, Tumino R, Bueno-De-Mesquita B, Peeters P, Berglund G, Hallmans G, Saracci R, Riboli E: Environmental tobacco smoke and risk of respiratory cancer and chronic obstructive pulmonary disease in former smokers and never smokers in the EPIC prospective study. Bmj 2005, 330:277.

49. Zhong L, Goldberg MS, Parent ME, Hanley JA: Exposure to environmental tobacco smoke and the risk of lung cancer: a meta-analysis. Lung Cancer 2000, 27:3-18.

50. Boffetta P, Agudo A, Ahrens W, Benhamou E, Benhamou S, Darby SC, Ferro G, Fortes C, Gonzalez CA, Jockel KH, Krauss M, Kreienbrock L, Kreuzer M, Mendes A, Merletti F, Nyberg F, Pershagen G, Pohlabeln H, Riboli E, Schmid G, Simonato L, Tredaniel J, Whitley E, Wichmann HE,
Winck C, Zambon P, Saracci R: Multicenter case-control study of exposure to environmental tobacco smoke and lung cancer in Europe. J Natl Cancer Inst 1998, 90:1440-1450.

51. Scientific bases for identification of potential carcinogens and estimation of risks. Interagency Regulatory Liaison Group, Work Group on Risk Assessment. Annu Rev Public Health 1980, 1:345-393.

52. Crump KS, Hoel DG, Langley CH, Peto R: Fundamental carcinogenic processes and their implications for low dose risk assessment. Cancer Res 1976, 36:2973-2979.

53. Doll $R$, Peto $R$ : The causes of cancer: quantitative estimates of avoidable risks of cancer in the United States today. J Natl Cancer Inst 1981, 66:1191-1308.

54. Garfinkel L: Time trends in lung cancer mortality among nonsmokers and a note on passive smoking. J Natl Cancer Inst 1981, 66:1061-1066.

55. Garfinkel L, Auerbach $O$, Joubert L: Involuntary smoking and lung cancer: a case-control study. J Natl Cancer Inst 1985, 75:463-469.

56. Phillips RL, Garfinkel L, Kuzma JW, Beeson WL, Lotz T, Brin B: Mortality among California Seventh-Day Adventists for selected cancer sites. J Natl Cancer Inst 1980, 65:1097-1107.

57. Phillips RL, Kuzma JW, Beeson WL, Lotz T: Influence of selection versus lifestyle on risk of fatal cancer and cardiovascular disease among Seventh-day Adventists. Am J Epidemiol 1980, 112:296-314.

58. Repace JL, Lowrey AH: Indoor air pollution, tobacco smoke, and public health. Science 1980, 208:464-472

59. Repace $\mathrm{J}$, Lowrey $\mathrm{AH}$ : An indoor air quality standard for ambient tobacco smoke based on carcinogenic risk. N Y State J Med 1985, 85:381-383.

60. Repace JL, Lowrey AH: Environmental tobacco smoke and indoor air quality in modern office work environments. J Occup Med 1987, 29(628629):632-624.

61. Repace $L$ : A quantitative estimate of nonsmokers' lung cancer risk from passive smoking. Environ Int 1985, 11:3-22.

62. Robins J: In Environmental Tobacco Smoke: Measuring Exposures and Assessing Health Effects. Edited by: N.R.C. Committee on Passive Smoking. Washington, D.C.: The National Academies Press; 1986:

63. Saracci R, Riboli E: Passive smoking and lung cancer: current evidence and ongoing studies at the International Agency for Research on Cancer. Mutat Res 1989, 222:117-127.

64. Wald NJ, Boreham J, Bailey A, Ritchie C, Haddow JE, Knight G: Urinary cotinine as marker of breathing other people's tobacco smoke. Lancet 1984, 1:230-231.

65. Stranges $S$, Bonner MR, Fucci F, Cummings KM, Freudenheim JL, Dorn JM, Muti P, Giovino GA, Hyland A, Trevisan M: Lifetime cumulative exposure to secondhand smoke and risk of myocardial infarction in never smokers: results from the Western New York health study, 1995-2001. Arch Intern Med 2006, 166:1961-1967.

66. Wakefield M, Cameron M, Inglis G, Letcher T, Durkin S: Secondhand smoke exposure and respiratory symptoms among casino, club, and office workers in Victoria, Australia. J Occup Environ Med 2005, 47:698-703.

67. Kreuzer M, Krauss M, Kreienbrock L, Jockel KH, Wichmann HE: Environmental tobacco smoke and lung cancer: a case-control study in Germany. Am J Epidemiol 2000, 151:241-250.

68. Skeer M, Cheng DM, Rigotti NA, Siegel M: Secondhand smoke exposure in the workplace. Am J Prev Med 2005, 28:331-337.

69. Puntoni R, Toninelli F, Zhankui L, Bonassi S: Mathematical modelling in risk/exposure assessment of tobacco related lung cancer. Carcinogenesis 1995, 16:1465-1471.

70. Repace JL, Lowrey AH: Risk assessment methodologies for passive smoking-induced lung cancer. Risk Anal 1990, 10:27-37.

71. Repace JL: Can Ventilation Control Secondhand Smoke in the Hospitality Industry? OSHA Ventilation Workshop An Analysis of the Document "Proceedings of the Workshop on Ventilation Engineering Controls for Environmental Tobacco Smoke in the Hospitality Industry", sponsored by the Federal Occupational Safety and Health Administration and the American Conference of Governmental Industrial Hygienists 2000.

72. Repace $J$, Lowrey $A H$ : An enforceable indoor air quality standard for environmental tobacco smoke in the workplace. Risk Anal 1993, 13:463-475.

73. Klepeis NE: An introduction to the indirect exposure assessment approach: modeling human exposure using microenvironmental 
measurements and the recent National Human Activity Pattern Survey Environ Health Perspect 1999, 107(Suppl 2):365-374.

74. Klepeis NE: Validity of the uniform mixing assumption: determining human exposure to environmental tobacco smoke. Environ Health Perspect 1999, 107(Suppl 2):357-363.

75. Klepeis NE, Ott WR, Switzer P: A multiple smoker model for predicting indoor air quality in public lounges. Environ Sci Technol 1996, 30:2813-2820.

76. Ott WR, Langan L, Switzer P: A time series model for cigarette smoking activity patterns: model validation for cabon monoxide and respirable particles in a chamber and an automobile. J Expo Anal Environ Epidemio 1992, 2:175-200

77. Ott WR: Mathematical models for predicting indoor air quality from smoking activity. Environ Health Perspect 1999, 107(Suppl 2):375-381.

78. U.S. Environmental Protection Agency: Respiratory health effects of passive smoking: lung cancer and other disorders. U.S. EPA: Washington, D.C 1992.

79. Akbar-Khanzadeh F: Exposure to environmental tobacco smoke in restaurants without separate ventilation systems for smoking and nonsmoking dining areas. Arch Environ Health 2003, 58:97-103.

80. Akbar-Khanzadeh F, Milz S, Ames A, Spino S, Tex C: Effectiveness of clean indoor air ordinances in controlling environmental tobacco smoke in restaurants. Arch Environ Health 2004, 59:677-685.

81. Bergman TA, Johnson DL, Boatright DT, Smallwood KG, Rando RJ: Occupational exposure of nonsmoking nightclub musicians to environmental tobacco smoke. Am Ind Hyg Assoc J 1996, 57:746-752.

82. Bohanon HR Jr, Piade JJ, Schorp MK, Saint-Jalm Y: An international survey of indoor air quality, ventilation, and smoking activity in restaurants: a pilot study. J Expo Anal Environ Epidemiol 2003, 13:378-392.

83. Bolte G, Heitmann D, Kiranoglu M, Schierl R, Diemer J, Koerner W, Fromme $\mathrm{H}$ : Exposure to environmental tobacco smoke in German restaurants, pubs and discotheques. J Expo Sci Environ Epidemiol 2008, 18:262-271.

84. Cenko C, Pisaniello D, Esterman A: A study of environmental tobacco smoke in South Australian pubs, clubs and cafes. Int I Environ Health Res 2004, 14:3-11.

85. Collet CW, Ross JA, Levine KB: Levine, Nicotine, RSP, and CO2 levels in bars and nightclubs. Environ Int 1992, 18:347-352.

86. Ellingsen DG, Fladseth G, Daae HL, Gjolstad M, Kjaerheim K, Skogstad M, Olsen R, Thorud S, Molander P: Airborne exposure and biological monitoring of bar and restaurant workers before and after the introduction of a smoking ban. J Environ Monit 2006, 8:362-368.

87. Gee IL, Watson AF, Carrington J, Edwards PR, van Tongeren M, McElduff P, Edwards RE: Second-hand smoke levels in UK pubs and bars: do the English Public Health White Paper proposals go far enough? J Public Health (Oxf) 2006, 28:17-23.

88. Hyvarinen MJ, Rothberg M, Kahkonen E, Mielo T, Reijula K: Nicotine and 3ethenylpyridine concentrations as markers for environmental tobacco smoke in restaurants. Indoor Air 2000, 10:121-125.

89. Jenkins RA, Counts RW: Occupational exposure to environmental tobacco smoke: results of two personal exposure studies. Environ Health Perspect 1999, 107(Suppl 2):341-348.

90. Johnsson T, Tuomi T, Hyvarinen M, Svinhufvud J, Rothberg M, Reijula K: Occupational exposure of non-smoking restaurant personnel to environmental tobacco smoke in Finland. Am J Ind Med 2003, 43:523-531.

91. Johnsson T, Tuomi T, Riuttala H, Hyvarinen M, Rothberg M, Reijula K: Environmental tobacco smoke in Finnish restaurants and bars before and after smoking restrictions were introduced. Ann Occup Hyg 2006, 50:331-341.

92. Kuusimaki L, Pfaffli P, Froshaug M, Becher G, Dybing E, Peltonen K: Determination of nicotine as an indicator of environmental tobacco smoke in restaurants. Am J Ind Med 1999, Suppl 1: 152-154.

93. Maskarinec MP, Jenkins RA, Counts RW, Dindal AB: Determination of exposure to environmental tobacco smoke in restaurant and tavern workers in one US city. J Expo Anal Environ Epidemiol 2000, 10:36-49.

94. Mulcahy M, Evans DS, Hammond SK, Repace JL, Byrne M: Secondhand smoke exposure and risk following the Irish smoking ban: an assessment of salivary cotinine concentrations in hotel workers and air nicotine levels in bars. Tob Control 2005, 14:384-388

95. Nebot M, Lopez MJ, Gorini G, Neuberger M, Axelsson S, Pilali M, Fonseca C, Abdennbi K, Hackshaw A, Moshammer H, Laurent AM, Salles J, Georgouli M,
Fondelli MC, Serrahima E, Centrich F, Hammond SK: Environmental tobacco smoke exposure in public places of European cities. Tob Control 2005, 14:60-63.

96. Siegel M: Involuntary smoking in the restaurant workplace. A review of employee exposure and health effects. JAMA 1993, 270:490-493.

97. Skogstad M, Kjaerheim K, Fladseth G, Gjolstad M, Daae HL, Olsen R, Molander P, Ellingsen DG: Cross shift changes in lung function among bar and restaurant workers before and after implementation of a smoking ban. Occup Environ Med 2006, 63:482-487.

98. Trout D, Decker J, Mueller C, Bernert JT, Pirkle J: Exposure of casino employees to environmental tobacco smoke. J Occup Environ Med 1998, 40:270-276.

99. Hedley AJ, McGhee SM, Repace JL, Wong LC, Yu MY, Wong TW, Lam TH: Risks for heart disease and lung cancer from passive smoking by workers in the catering industry. Toxicol Sci 2006, 90:539-548.

100. Mulcahy M, Repace JL: Passive smoking exposure and risk for Irish bar staff in 9th International Conference on Indoor Air Quality and Climate. Monterrey, California, USA 2002

101. Jamrozik K: Estimate of deaths attribu to passive smoking among UK adults: database analysis. BMJ 2005, 330:812.

102. Woodward A, Laugesen M: Deaths in New Zealand attributable to second hand cigarette smoke. New Zealand Ministry of Health, Wellington 2000, 1-15.

103. Archer VE, Coons T, Saccomanno G, Hong DY: Latency and the lung cancer epidemic among United States uranium miners. Health Phys 2004, 87:480-489.

104. Rosenbaum WL, Sterling TD, Weinkam JJ: A critical examination of OSHA's assessment of risk associated with workplace exposure to environmental tobacco smoke. Regul Toxicol Pharmacol 1996, 23:233-240.

105. Rosenbaum WL, Sterling TD, Weinkam JJ: Linear extrapolation models of lung cancer risk associated with exposure to environmental tobacco smoke. Regul Toxicol Pharmacol 1998, 28:106-114.

106. Francis JA, Shea AK, Samet JM: Challenging the epidemiologic evidence on passive smoking: tactics of tobacco industry expert witnesses. Tob Control 2006, 15(Suppl 4):iv68-76.

107. Howard DJ, Ota RB, Briggs LA, Hampton M, Pritsos CA: Oxidative stress induced by environmental tobacco smoke in the workplace is mitigated by antioxidant Supplementation. Cancer Epidemiol Biomarkers Prev 1998, 7:981-988.

108. Shields PG: Understanding population and individual risk assessment: the case of polychlorinated biphenyls. Cancer Epidemiol Biomarkers Prev 2006, 15:830-839.

109. Thun MJ, Hannan LM, Adams-Campbell LL, Boffetta P, Buring JE, Feskanich D, Flanders WD, Jee SH, Katanoda K, Kolonel LN, Lee IM, Marugame T, Palmer JR, Riboli E, Sobue T, Avila-Tang E, Wilkens LR, Samet JM: Lung Cancer Occurrence in Never-Smokers: An Analysis of 13 Cohorts and 22 Cancer Registry Studies. PLoS Med 2008, 5:e185.

110. Repace J, Al-Delaimy WK, Bernert JT: Correlating atmospheric and biological markers in studies of secondhand tobacco smoke exposure and dose in children and adults. J Occup Environ Med 2006, 48:181-194.

111. Tweedie RL, Mengersen KL: Meta-analytic approaches to dose-response relationships, with application in studies of lung cancer and exposure to environmental tobacco smoke. Stat Med 1995, 14:545-569.

112. Ahrens $D$, Uebelher P, Remington PL: Evaluation of community and organizational characteristics of smoke-free ordinance campaigns in 15 Wisconsin cities. Prev Chronic Dis 2005, 2:A08.

doi:10.1186/1476-069X-9-49

Cite this article as: Kolb et al:: Quantification of ETS exposure in

hospitality workers who have never smoked. Environmental Health 2010 9:49. 